\title{
In silico identification of common and specific signatures in coronary heart diseases
}

\author{
ZHIJIA YANG ${ }^{1}$, HAIFANG MA ${ }^{2}$ and WEI LIU ${ }^{3}$ \\ ${ }^{1}$ The Third Department of Cardiovascular Medicine, Handan Central Hospital; \\ ${ }^{2}$ The First Department of Cardiovascular Medicine, Affiliated Hospital of Hebei University of Technology, \\ Handan, Hebei 056002; ${ }^{3}$ The First Department of Cardiovascular Medicine, \\ Handan Central Hospital, Handan, Hebei 056001, P.R. China
}

Received January 3, 2020; Accepted April 15, 2020

DOI: $10.3892 / \mathrm{etm} .2020 .9121$

\begin{abstract}
Coronary heart disease (CHD) is on the increase in developing countries, where lifestyle choices such as smoking, bad diet, and no exercise contribute and increase the incidence of high blood pressure and high cholesterol levels to cause CHD. Through utilization of a biomarker-based approach for developing interventions, the aim of the study was to identify differentially expressed genes (DEGs) and their association and impact on various bio-targets. The microarray datasets of both healthy and CHD patients were analyzed to identify the DEGs and their interactions using Gene Ontology, PANTHER, Reactome, and STRING (for the possible associated genes with multiple targets). Our data mining approach suggests that the DEGs were associated with molecular functions, including protein binding (75\%) and catalytic activity (56\%); biological processes such as cellular process $(83 \%)$, biological regulation (57\%), and metabolic process (44\%); and cellular components such as cell (65\%) and organelle (58\%); as well as other associations including apoptosis, inflammatory, cell development and metabolic pathways. The molecular functions were further analyzed, and protein binding in particular was analyzed using network analysis to determine whether there was a clear association with CHD and disease. The ingenuity pathway analysis revealed pathways related to cell cholesterol biosynthesis, the immune system including cytokinin signaling, in which, the understanding of DEGs is crucial to predict the advancement of preventive strategies. Results of the present study showed that, there is a need to validate the top DEGs to rule out their molecular mechanism in heart failure caused by CHD.
\end{abstract}

Correspondence to: Dr Wei Liu, The First Department of Cardiovascular Medicine, Handan Central Hospital, 15 Zhonghua North Street, Handan, Hebei 056001, P.R. China

E-mail: liuwei_1975@sina.com

Key words: coronary heart disease, microarray, differentially expressed genes

\section{Introduction}

Coronary heart disease (CHD), also known as coronary artery disease (CAD) is one of a group of diseases of the heart blood vessels affecting millions of individuals worldwide. According to the center for disease control (CDC) reports, each death out of four is related to heart diseases, leading to approximately 610,000 mortalities annually worldwide (1). Among the heart diseases, CAD is the most common, responsible for the death of 370,000 individuals annually worldwide (1). CAD occurs when the elasticity of arteries, as well as vein and vessel smoothing, become plaque in the inner wall, making them rigid and narrowed. This condition restricts the blood flow to the heart muscle, leading to oxygen starvation. The condition of plaque rupture leads to the heart failure or cardiac death (2).

Recently, there has been an increase in the incidence of CHD (also known as ischemic heart disease) in China (3). In addition, CHD has become the most common reason for death in middle and high-income countries (4). According to the data report by NHANES, CHD prevalence was higher in males than females across all ages (7.4 v/s 5.3\%, respectively) (3). The American Heart Association explains 'The important difference between sex and pathology', clinical presentation and outcomes in CHD patients (5). Thus it is crucial to pay attention to sex disparities and subsequently to personalize treatment (6). Patients with CHD are also susceptible to more complicated clinical problems. Currently, the diagnosis and therapy of CHD is rare and costly as compared to coronary angiography, which is the most popular clinical management option (7). CHD is one of the leading causes of death, and markedly affects the immunity of the body, making it an economic burden worldwide $(8,9)$. This is a complex disease involving multiple mechanisms and influenced by many risk factors, including physical activity, genetics, diet, and smoking $(10,11)$. Recently, a genome-wide association study (GWAS) identified many candidate loci associated with CHD and myocardial infection (MI) (12-14). Although genetics play an important role, accounting for approximately $50 \%$ of CHD heritability, the exact mechanism and causative agent of CHD are not yet revealed clearly (15-17). In this regard, it is important to understand and address the candidate genome association in developing CHD. 


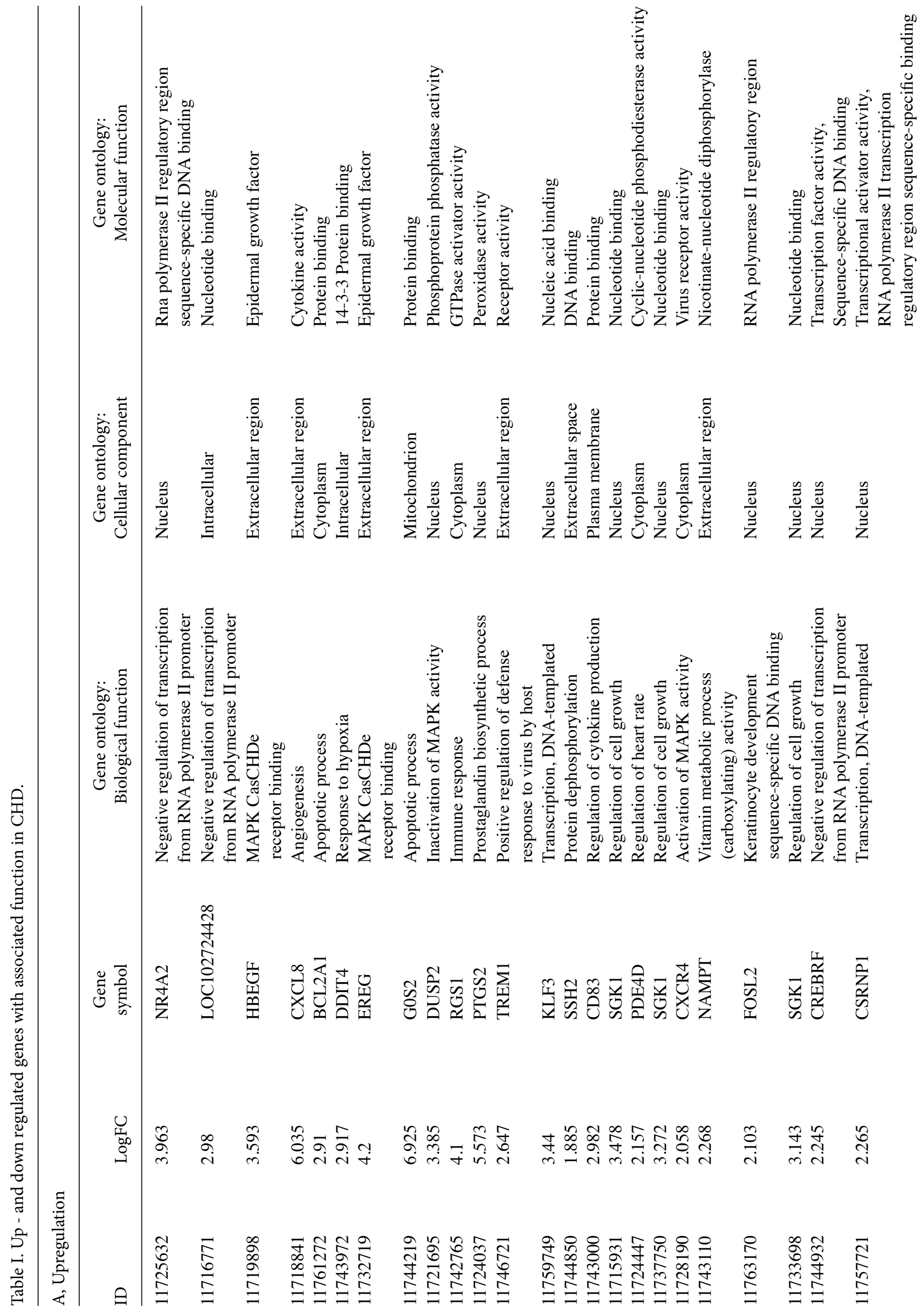




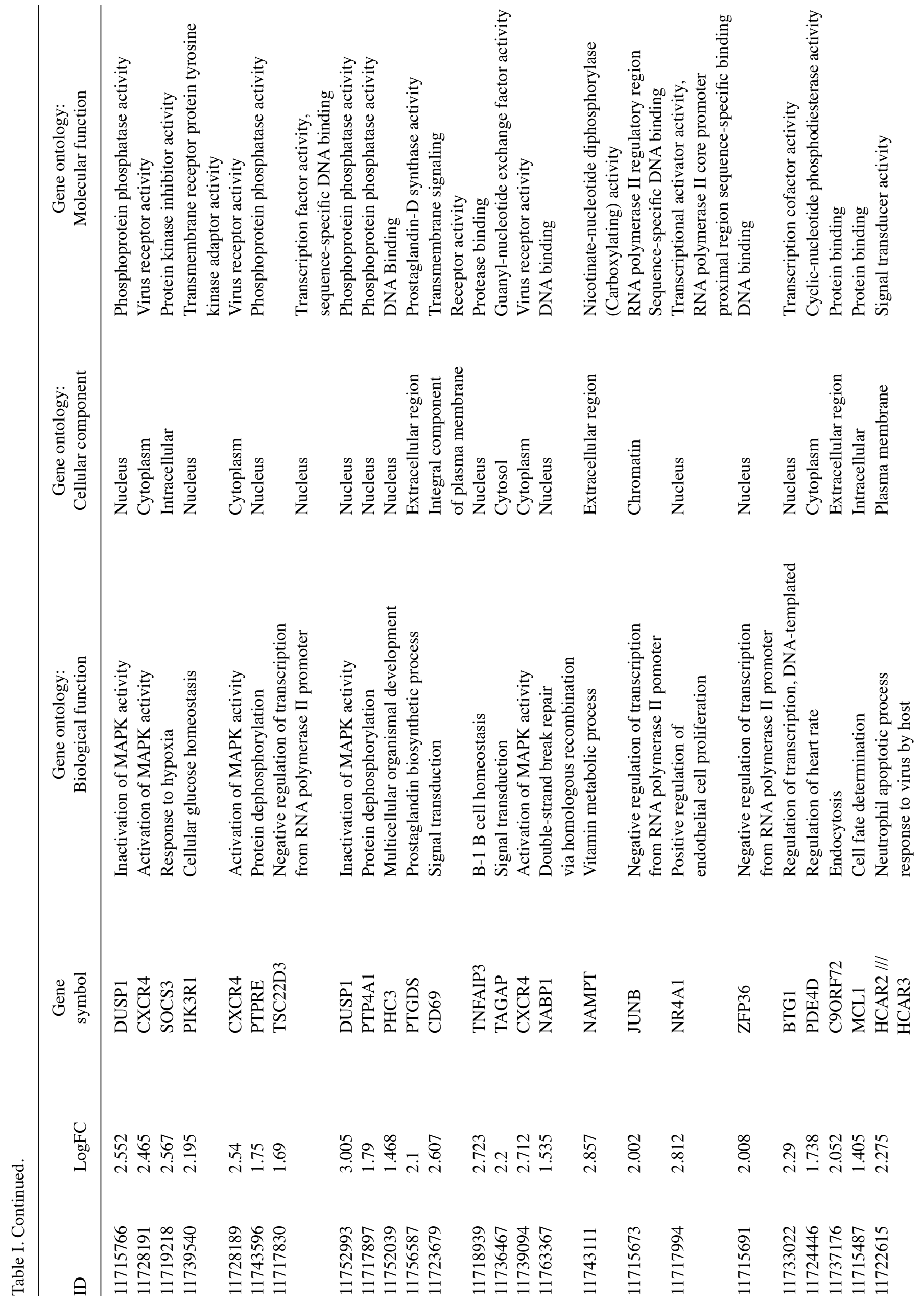




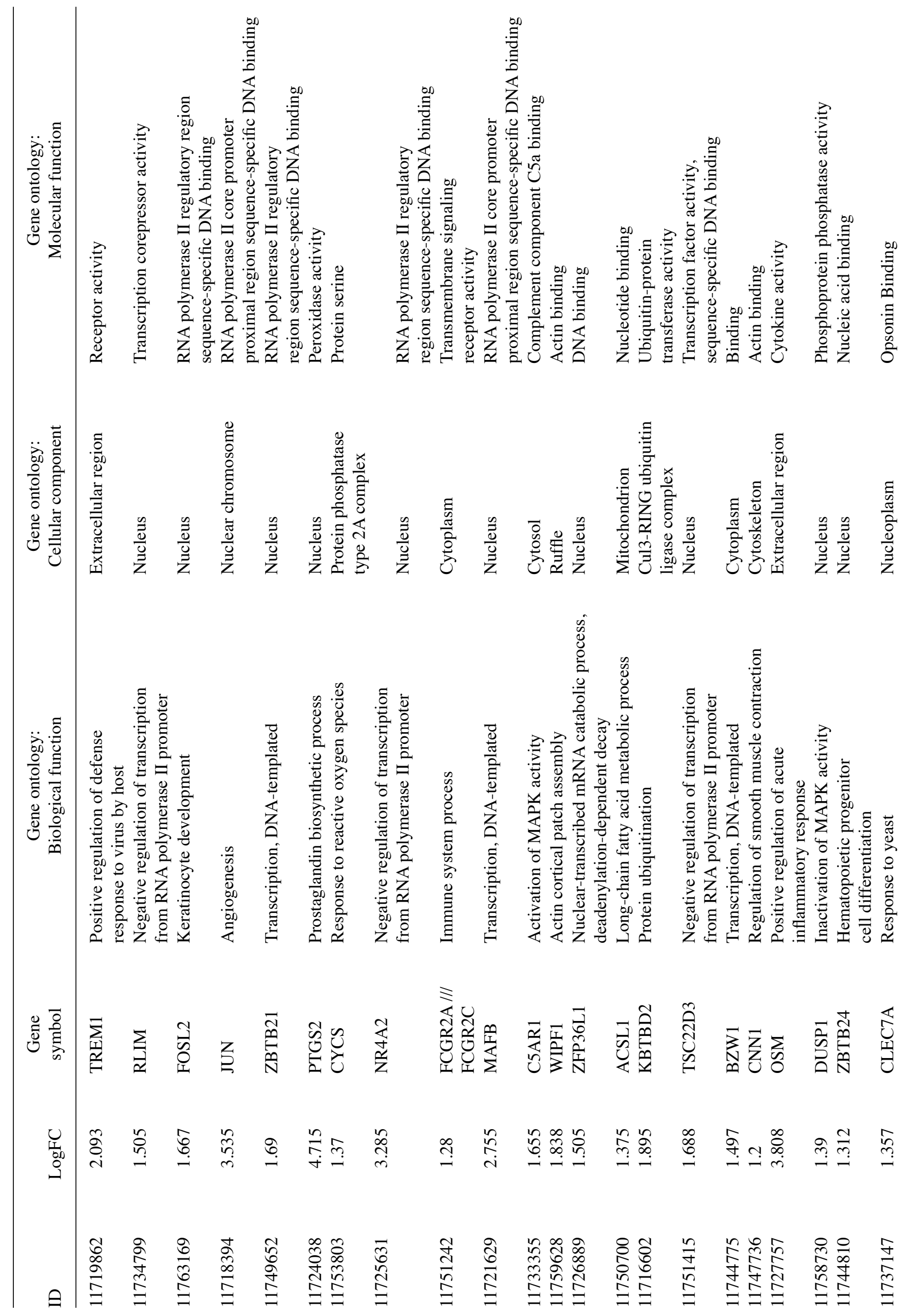




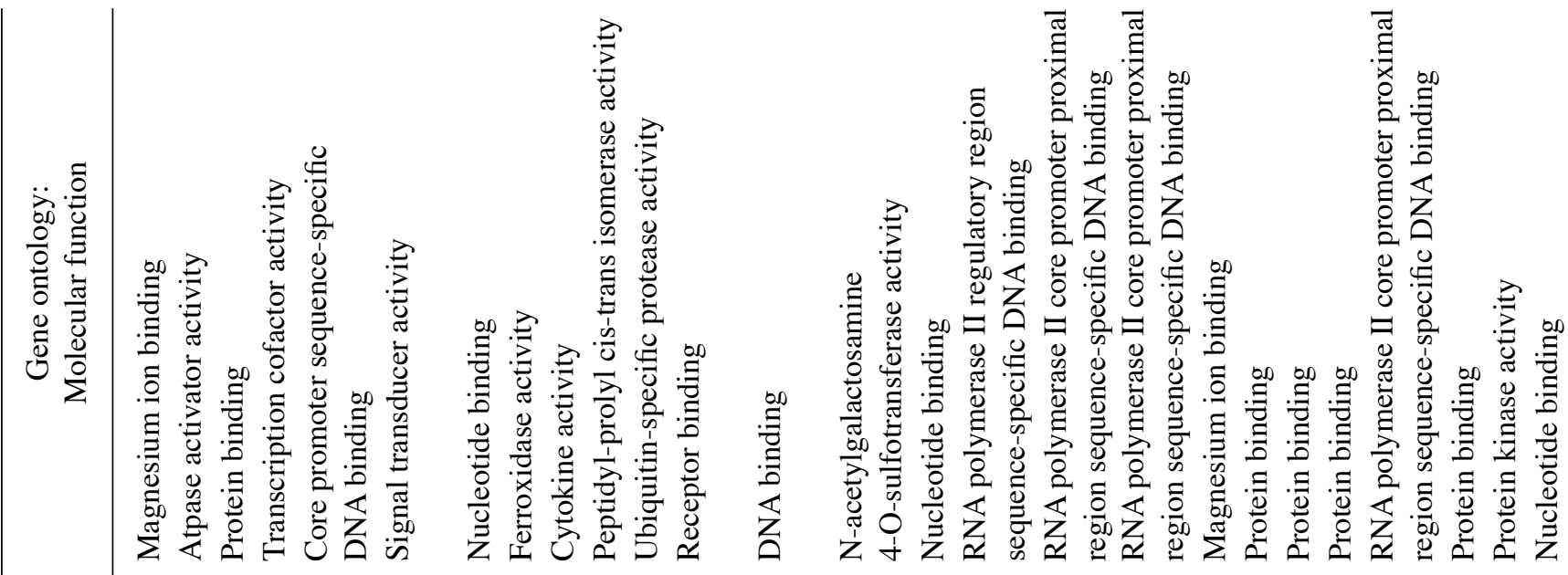

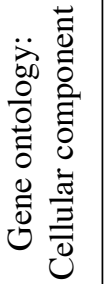

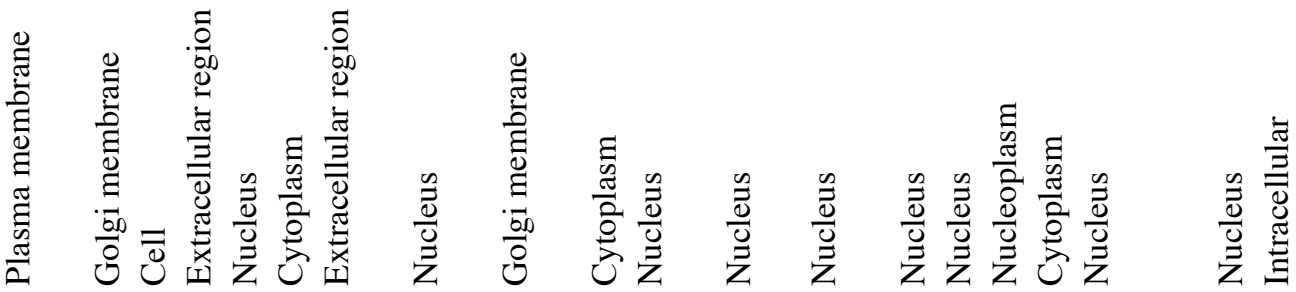

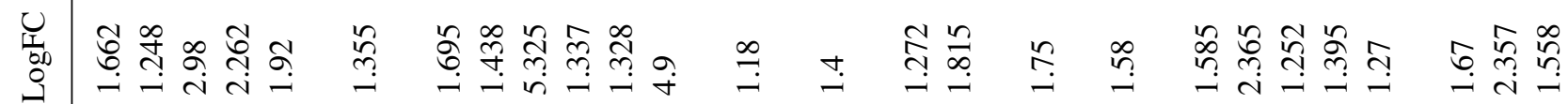

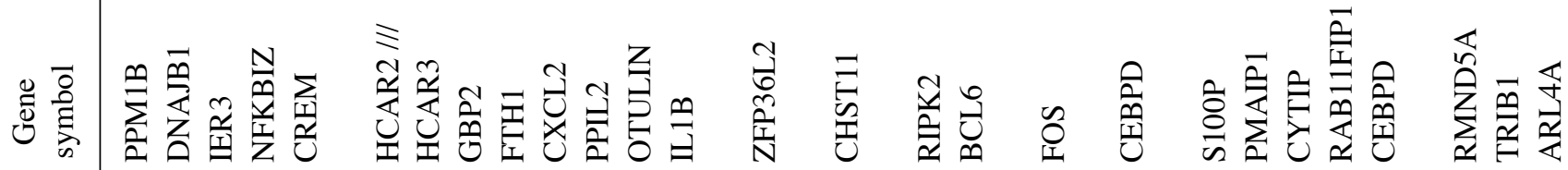

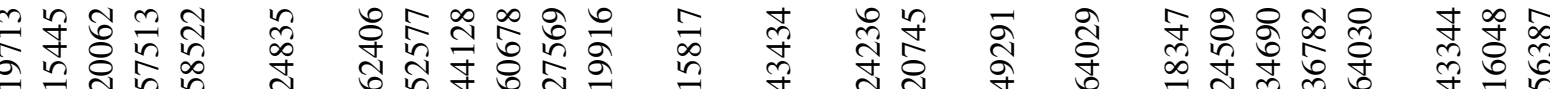

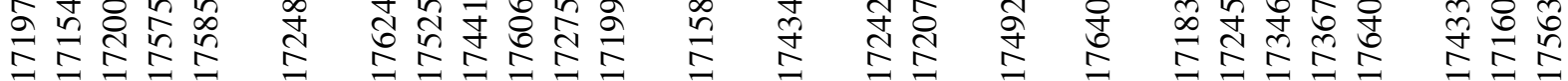




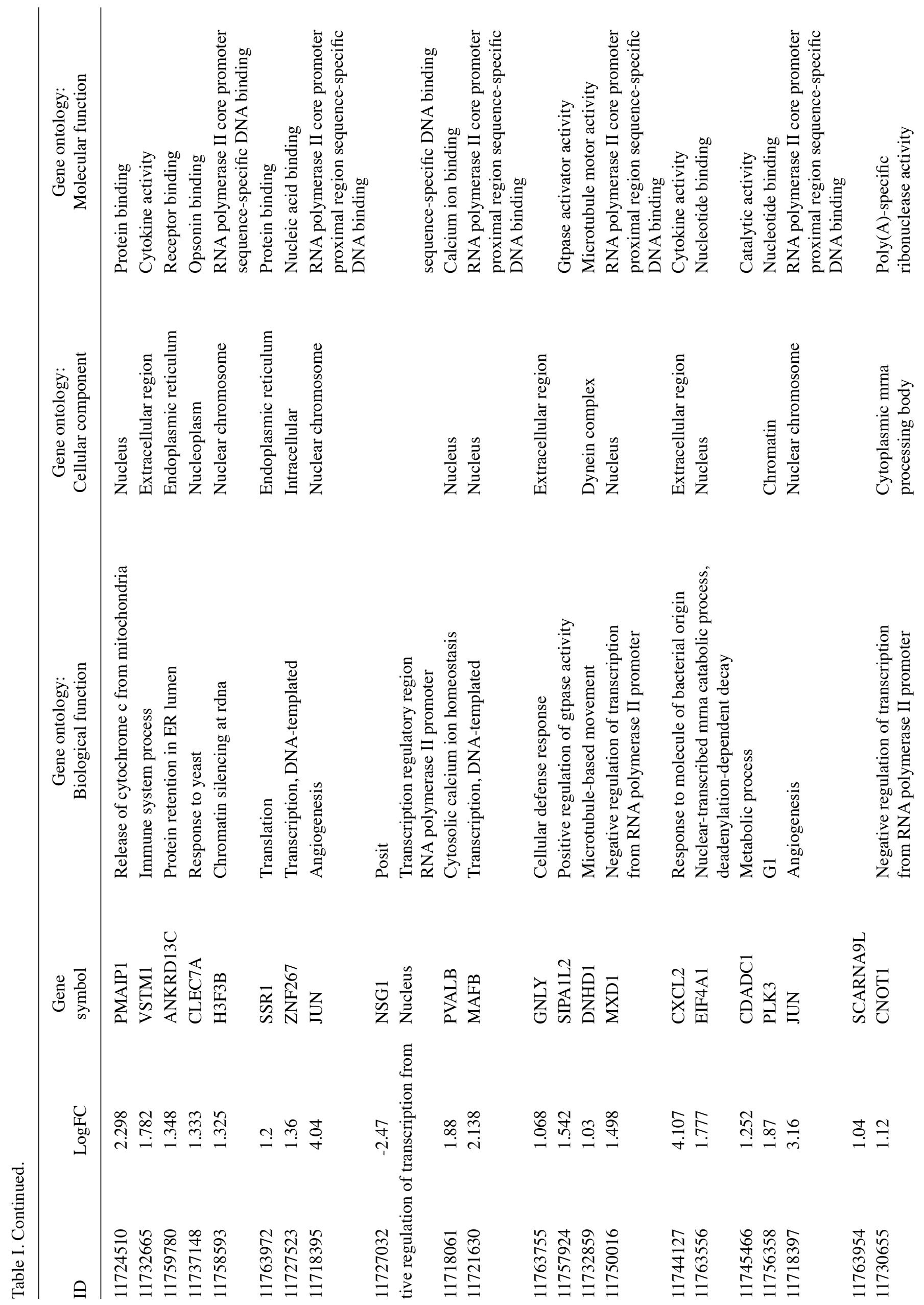




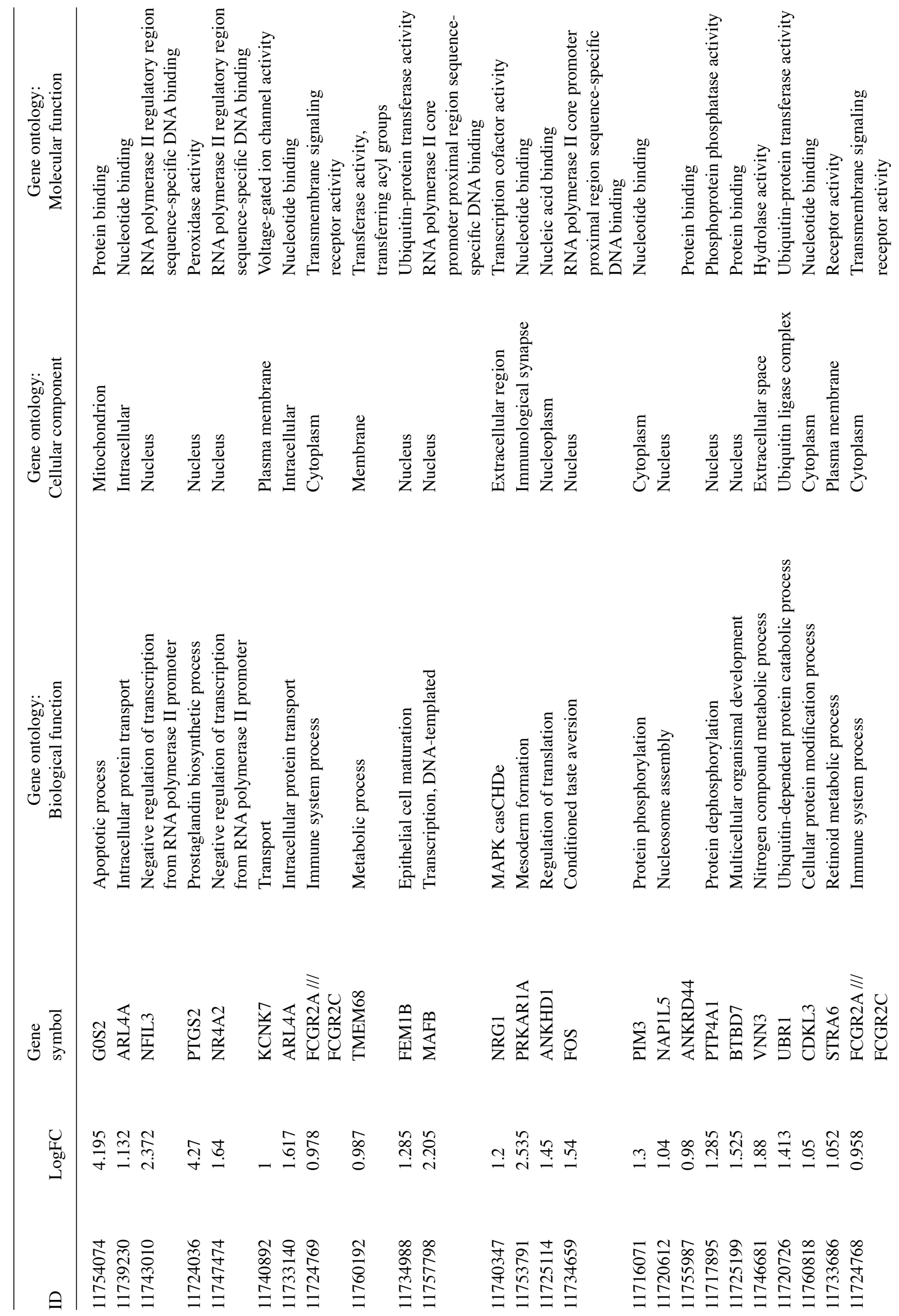




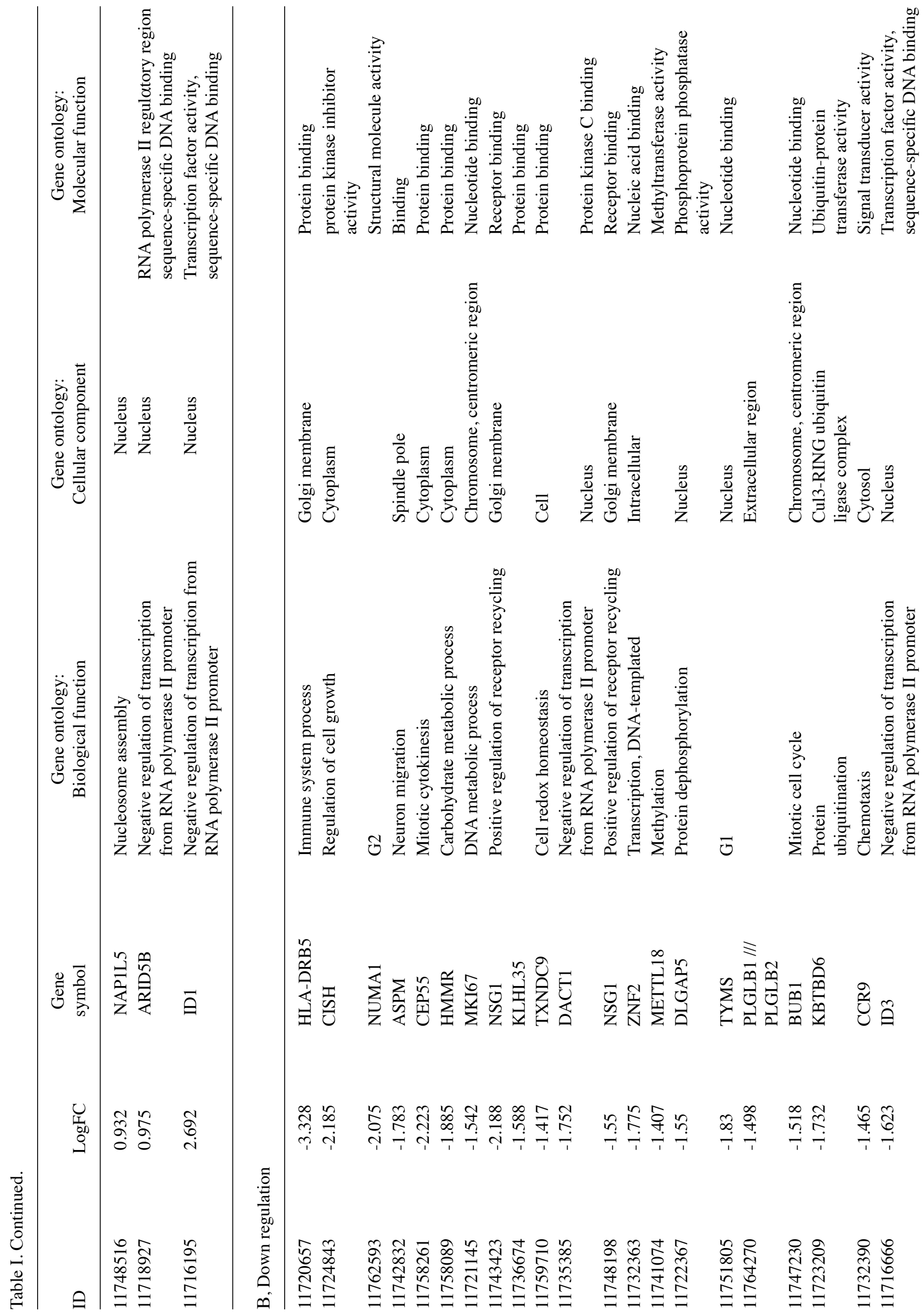




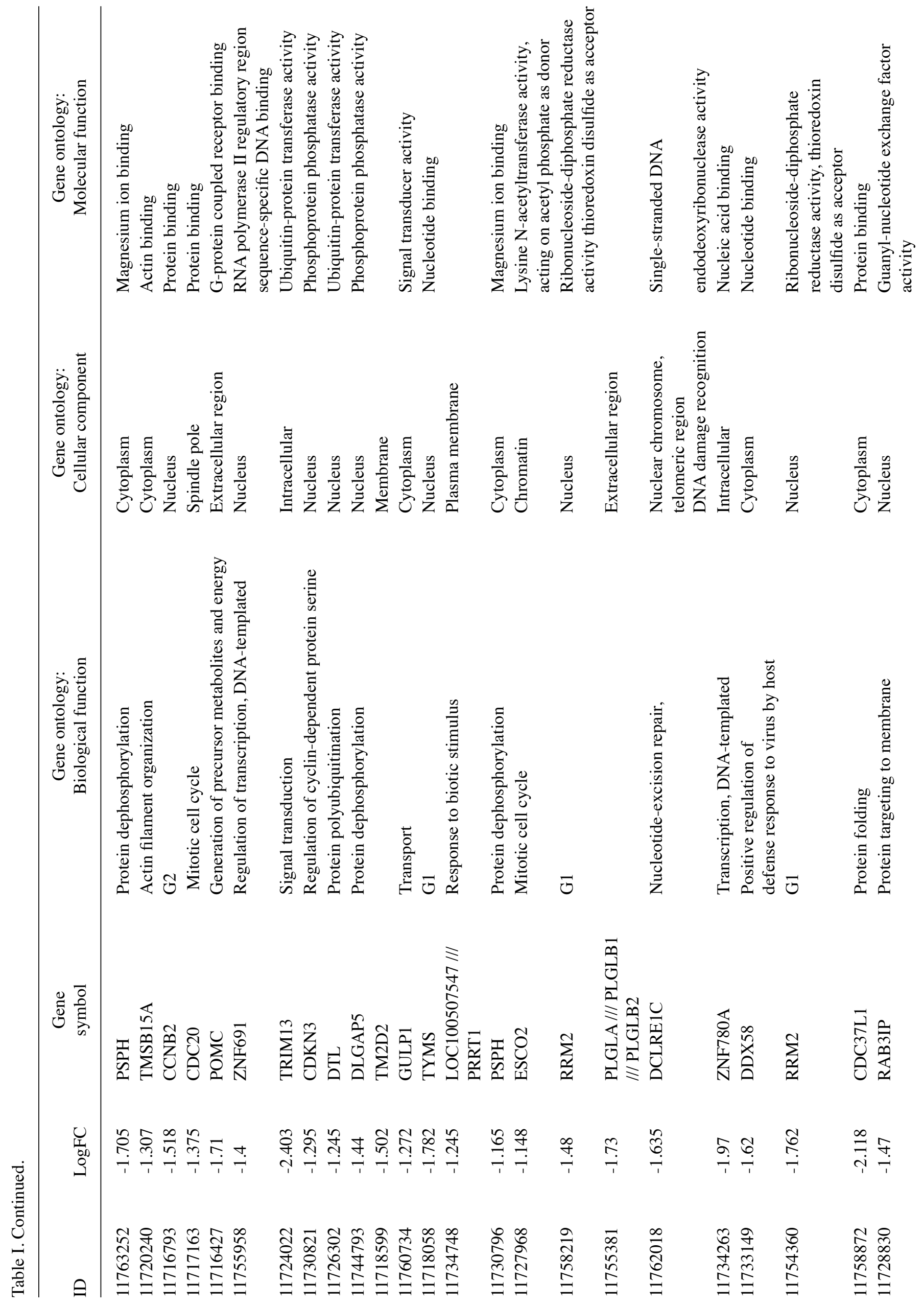




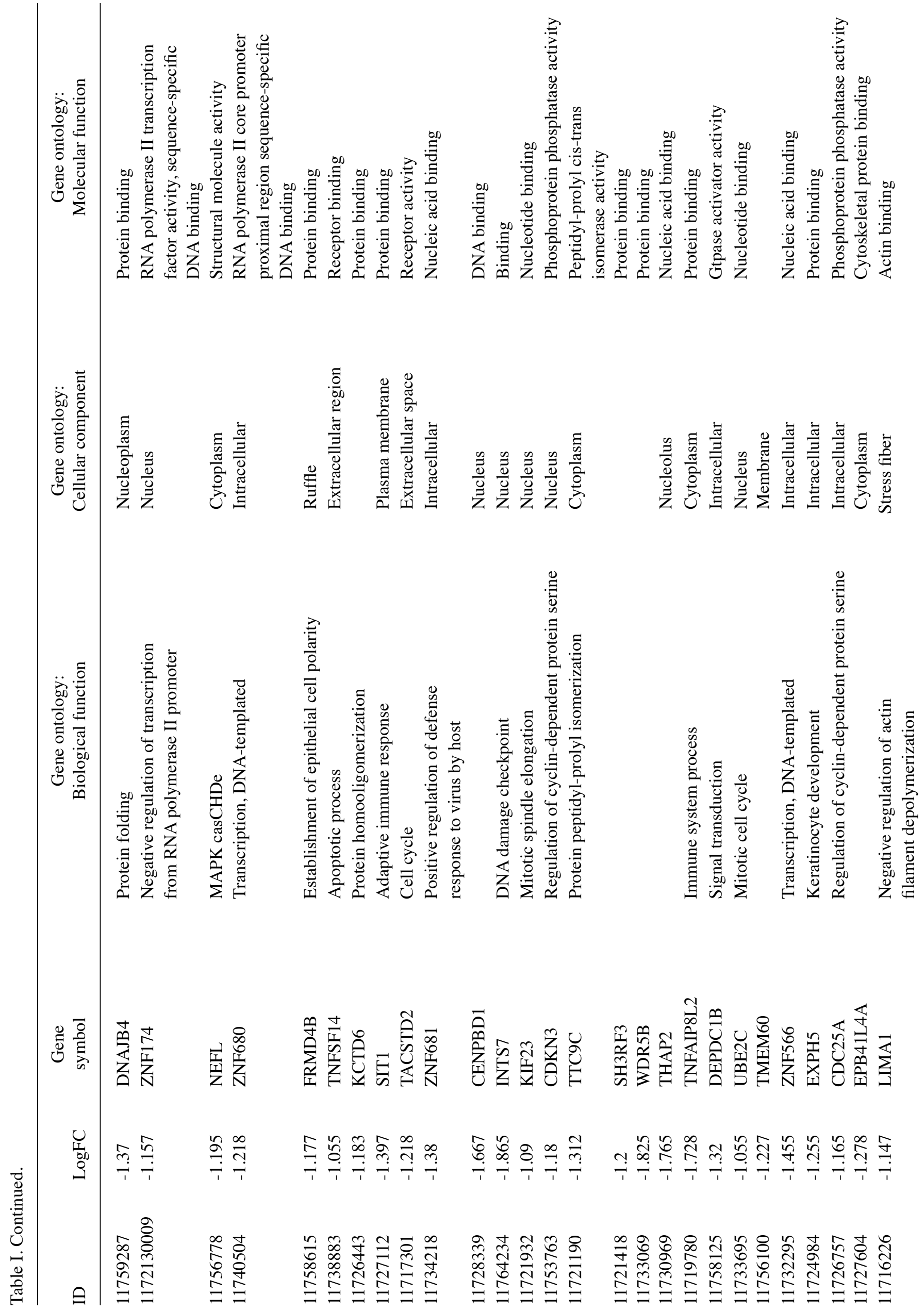




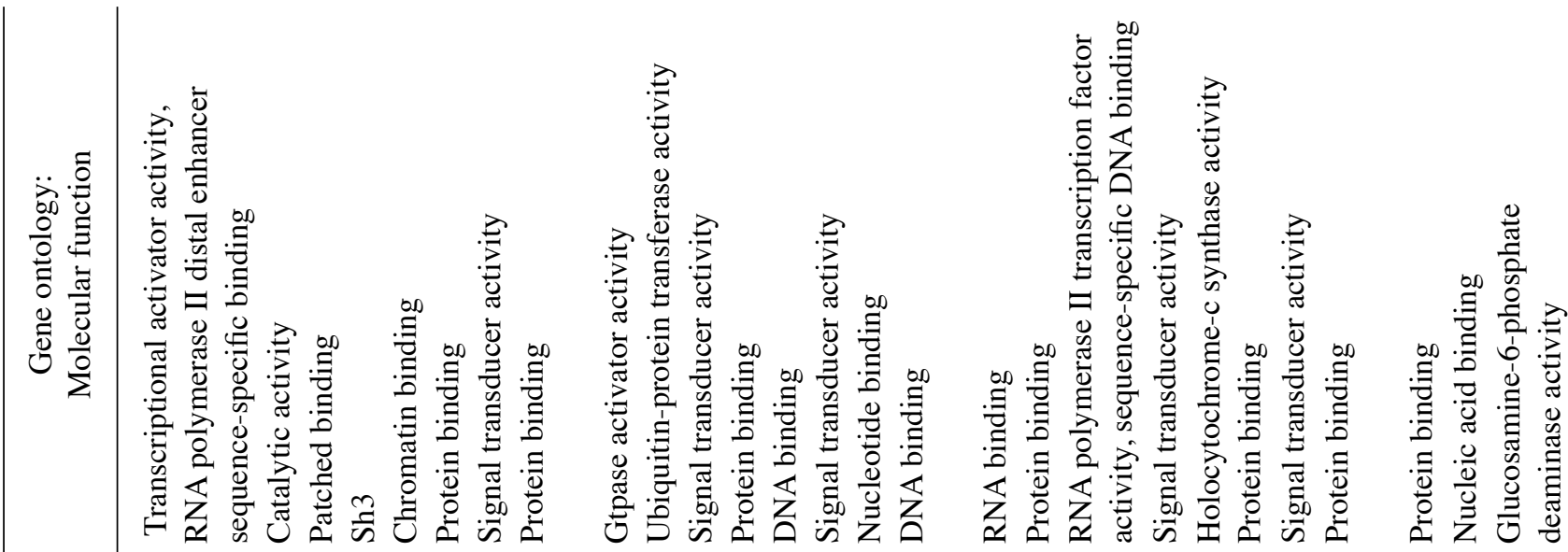

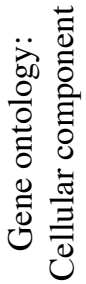

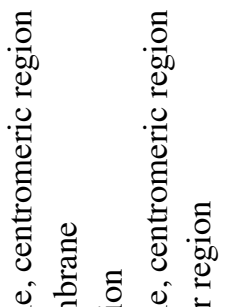

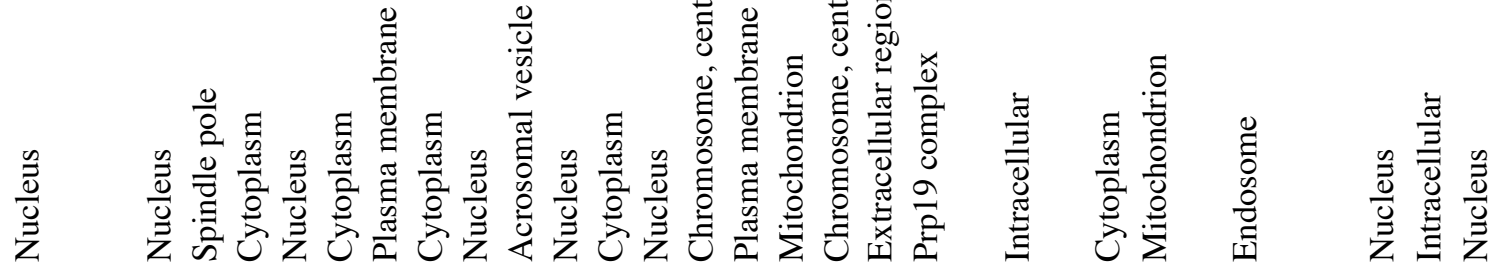

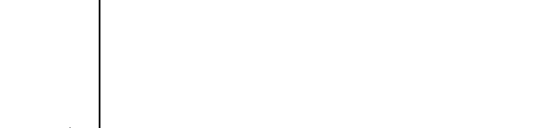

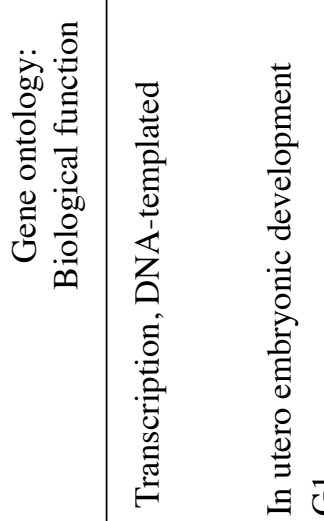

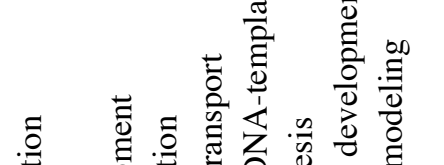

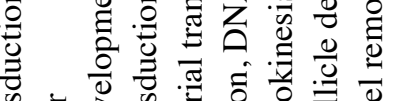

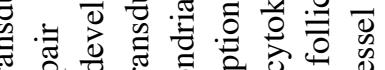

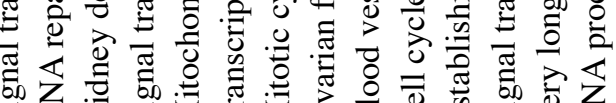

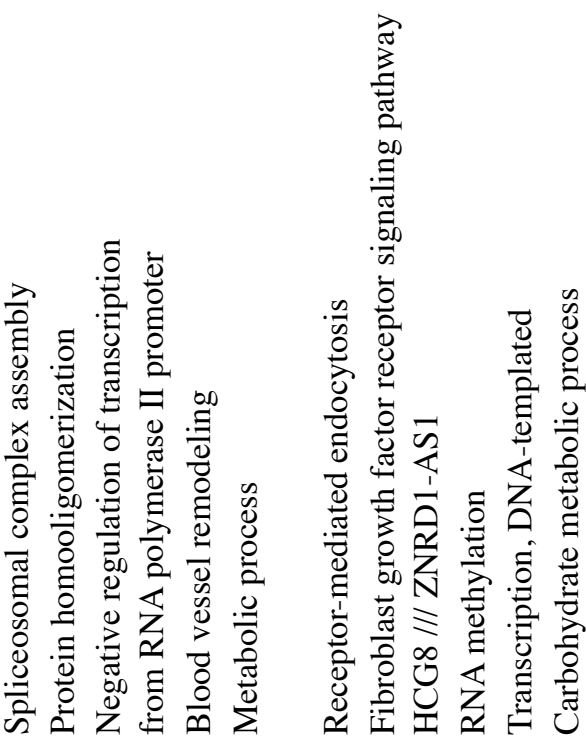

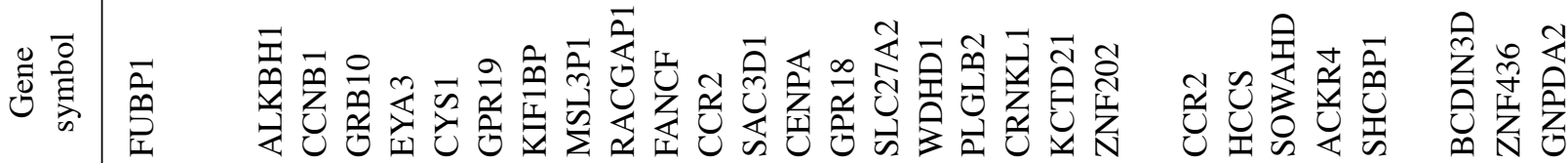

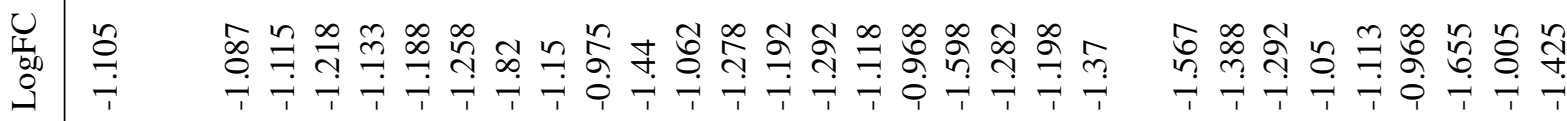

लె

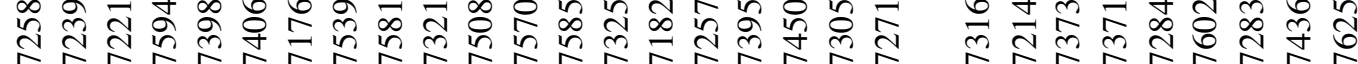

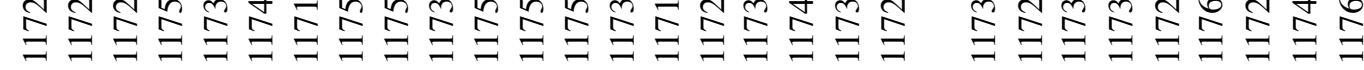


MicroRNAs (miRNA) are small noncoding RNAs with a length of 22-25 nucleotide and which play a key role in the regulation of gene expression and have implications in many human disorders (18), including many biological processes such as cell differentiation, proliferation and apoptosis (19-21). To the best of the knowledge of the authors, the association pattern of miRNAs to CHD is lacking, leading to demand for specific CHD patients. Although relevant research has been undertaken to address DEGs associated with CHD, DEGs have only been used to check the expression pattern in case of CHD. In this study, we addressed the possible association of genes with CHD, which may be useful for the diagnosis and treatment of this disease in the near future. Additionally, analysis of gene expression data and network analysis were performed to gain a better understanding of CHD for the identification of differentially expressed genes (DEGs), biomarkers and therapeutic target options.

\section{Materials and methods}

Data availability. To identify key genes for the development of CHD biomarkers, we used gene expression datasets of 4 angiographically proven patients who were being treated for more than 3 months or from group-1 $(n=100)$ compared to healthy control $(n=50)$. This dataset was downloaded from the GEO module of National Center for Biotechnology Information (https://www.ncbi.nlm.nih.gov/geo/query/acc. cgi?acc $=$ GSE56885). Microarray gene expression profiles were downloaded and further analyzed for the identification of DEGs. In this dataset, GSM1370681 and GSM1370682 represent the replicate samples of healthy individuals and GSM1370683 to GSM1370686 of four patients as baseline associated with CAD.

Differential Expression Analysis (DEG). Using the default parameters, WEGO 2.0, and GEO2R (https://www.ncbi.nlm. nih.gov/geo/geo2r/) were used to analyze the GEO series (22). The Benjamini and Hochberg false discovery rate method was utilized to adjust the P-values. NCBI-generated annotations were employed to display the DEG list by comparing the overall common gene expression pattern as compared to the control. On the basis of this analysis, possible associations related to CHD were reported. Although inappropriate to consider the data for analysis on inter-datasets, the average value of $\operatorname{LogFC}$ for all four datasets was assessed to represent the expression level.

Gene ontology $(\mathrm{GO})$ analysis. The major bioinformatics tool $\mathrm{GO}$ was used as an initiative to understand the function of genes and gene products of Homo sapiens. The PANTHER (Protein ANalysis THrough Evolutionary Relationships) classification database (23) was used to perform the GO analysis, and the pathway analysis was performed using Reactome (24).

Protein-Protein Interaction (PPI) network construction analysis. An online freely available software package, STRING, was utilized to establish the PPI network (25), and all the cut-off points were combined to analyze the topology property of networks. Gene edges of $>15$ degrees were defined as hub genes.

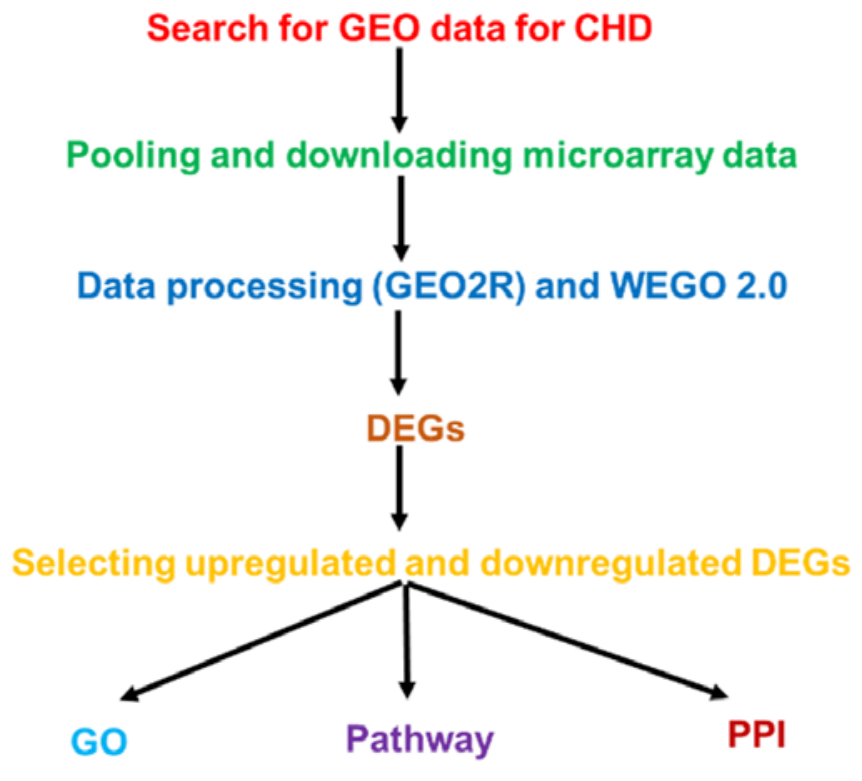

Figure 1. Designing of CHD data set for DEGs study.

\section{Results and Discussion}

Screening of differentially expressed common genes from microarray data sets. Atherosclerosis is one of the leading causes of cardiovascular diseases such as CHD (26). Understanding of the key players in expression, regulation and function, of GWAS CHD genes will provide the options to treat this disease, leading to further developments of novel therapeutic interventions (27). In this study, the first compressive investigation was conducted to identify the expression profile of collected microarray data sets of CHD. The dataset of two controls in replicate and four baseline test samples were used. We report an overall expression and function of genes associated with different biological processes, which may lead to CHD during pathological conditions. The overall study design is shown in Fig. 1, which presents CHD data of Homo sapiens from the GEO database, with four series of test samples and two control study sets. First, we used WEGO to visualize the GO annotations and the percentage of genetic association of different functions in cells to address the possible association with CHD.

A total of 52,998 genes sharing different functions such as cellular $(18,476)$, biological $(17,307)$ and molecular $(17,215)$ functions were identified. Out of those, the highest gene association to cell, cell part, organelle, organelle part, membrane, binding, cellular process, biological regulation, and metabolic were topmost in the metadata of the CHD-associated data set (Fig. 2). The different GO representing the $0-90 \%$ range of gene expression as compared to control data set is shown in Fig. 3. The principal findings of this study confirm the association of immune system, inflammation, and apoptosis as mediators in the development of CHD. The impact of the immune system plays a key role in the development of heart failure. A transcriptomic study reported the sustained activation of the adoptive immune system which may be a contributing factor 


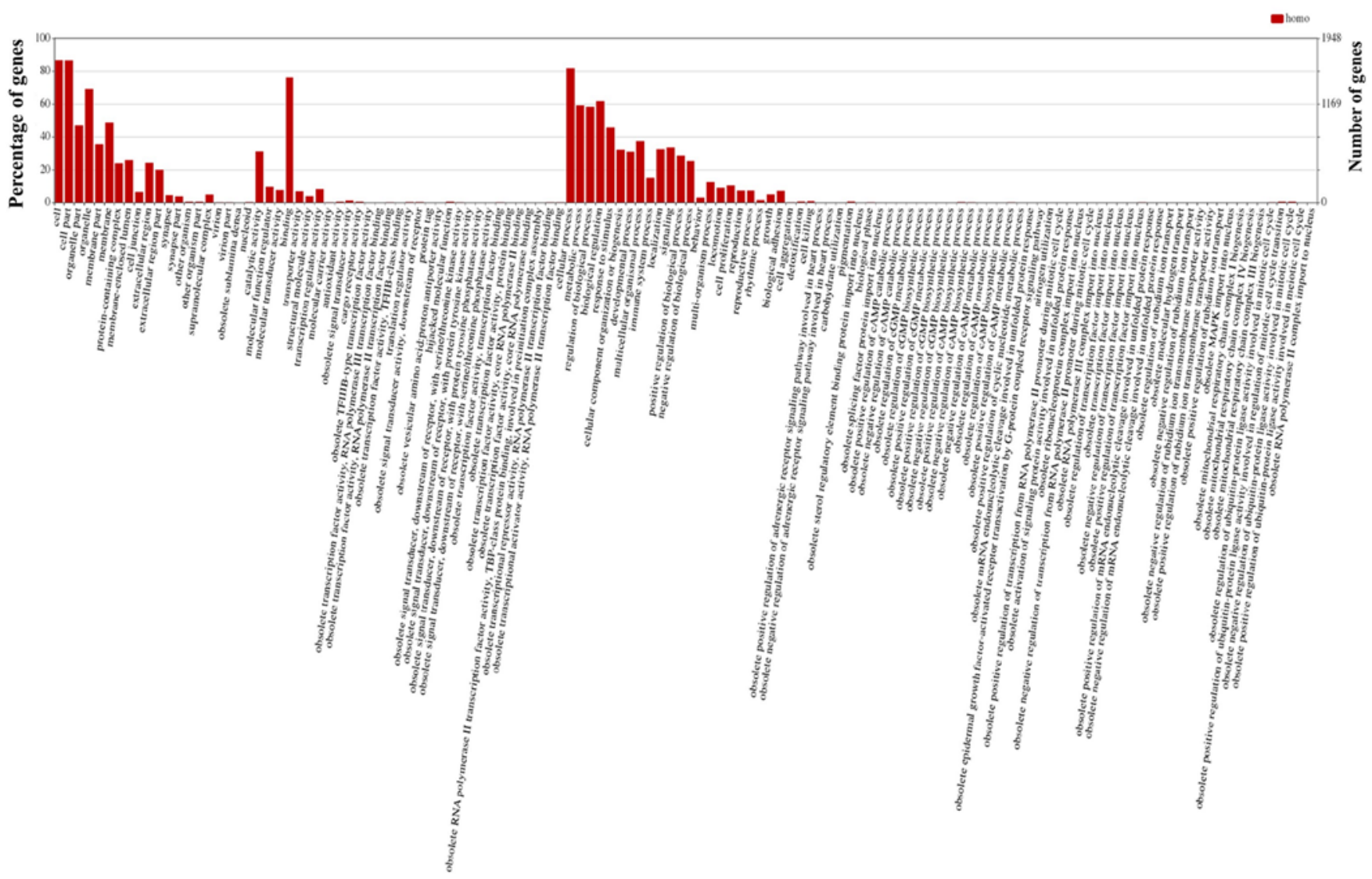

$\begin{array}{lll}\text { Cellular component } & \text { Molecular functions } & \text { Biological process }\end{array}$

Figure 2. Up- and downregulated gene association comparing all the genetic data set.

in the progression of CHD (28). Another report suggests that the imbalance in inflammatory and anti-inflammatory cytokines may lead to the onset of extensive fibrosis (29).

From the GEO database, accession GSE56885 of CSD patients, who were being treated for more than 3 months was selected. From the included patients, two controls in replicate and four overall test samples were used to consolidate data refining. The GEO2R was used to analyze the control and test data series by normalizing the microarray data for high quality. DEGs with different fold change confirm their crucial role in CHD (Table I).

In our study, many immune response processes were significantly changed and DEGs are associated with the metabolic process, which is associated with CHD. The CHDs of the innate immune system were largely mediated through neutrophils and monocyte, and macrophages (30), to contribute to the process of the chronic inflammation process.

Functional enrichment and unified DEG analysis. To precisely understand the gene changes during CHD, the DEGs GO was performed using the online PANTHER database for highthroughput analysis to classify the proteins and their genes into family and subfamily, molecular function, biological process, and pathway (31). In the dataset analyzed, the two significant changes in molecular function were protein binding $(75 \%)$ and catalytic activity (56\%), followed by molecular regulator, molecular transducer activity, structural activity, transcription regulator activity, and transporter activity (Fig. 4A). In terms of the biological process, the three most significant classes of CHD were cellular process $(83 \%)$, biological regulation (57\%), and metabolic process (44\%) (Fig. 4B). Additionally, in terms of cellular components, another two more significant components are cell $(65 \%)$ and organelle (58\%), which were found to be associated with CHD (Fig. 4C). Many other targetassociated DEGs were involved in the biological process, molecular function and cellular components.

Analyzed potential DEGs of the CHD data set shows protein classes distributed among transcription factor (24\%), enzyme modulator (20\%), nucleic acid binding (18\%), and signaling molecules (18\%) (Fig. 5A). The DEGs mainly associated with CHD key pathways showed the significance are inflammation mediated by chemokine and cytokine signaling pathway (11\%), CCKR signaling map (11\%), gonadotropin-releasing hormone receptor pathway $(8 \%)$, apoptosis signaling pathway $(6 \%)$, and p53 pathway (5\%) (Fig. 5B). This result was consistent with 


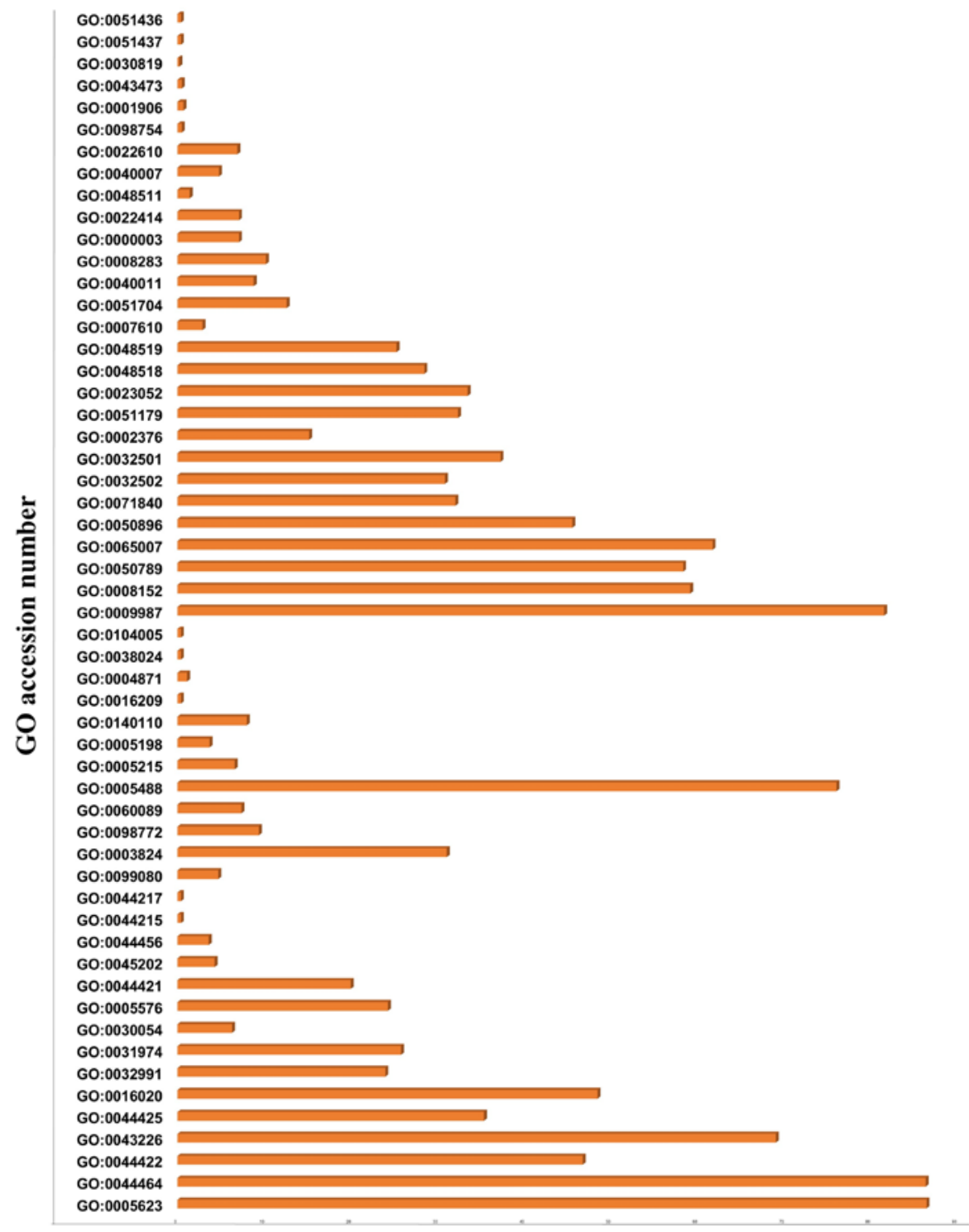

\section{Percentage}

Figure 3. GO analysis of the microarray CHD data set. The x-axis shows selected GO terms, and y-axis is the percentage of the gene association from selected data set.

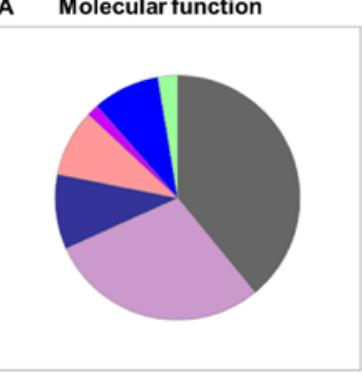

- Binding (GO:0005488)

Catalytic activity (GO:0003824)

Molecular function regulator (GO:0098772)

Molecular transducer activity (GO:0060089)

Structural molecule activity (GO:0005198)

Transcription regulator activity (GO:0140110)

Transporter activity (GO:0005215)
B

Biological process

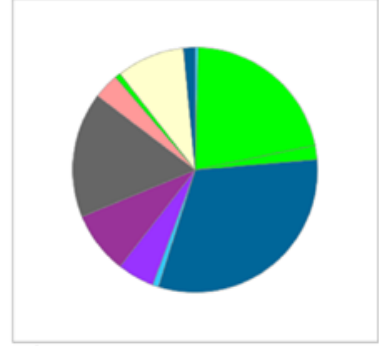

- Biological adhesion (GO:0022610) Biological regulation (GO:0065007) - Cell proliferation (GO:0008283)

- Cellular process (GO:0009987)

- Developmental process (GO:0032502)

- Immune system process (GO:0002376)

- Immune system process (GOation (GO:0051179)

localization (GO:0051179)

Multicellular organismal process (GO:0032501)

- Reproduction (GO:0000003)

Response to stimulus (GO:0050896)

- Rhythmic process (GO:0048511)

Figure 4. Analyzed Gene ontology (GO) of DEGs in CHD. Enriched GO terms in the (A) molecular function class, (B) biological process class, and (C) cellular component class of common DEGs. 


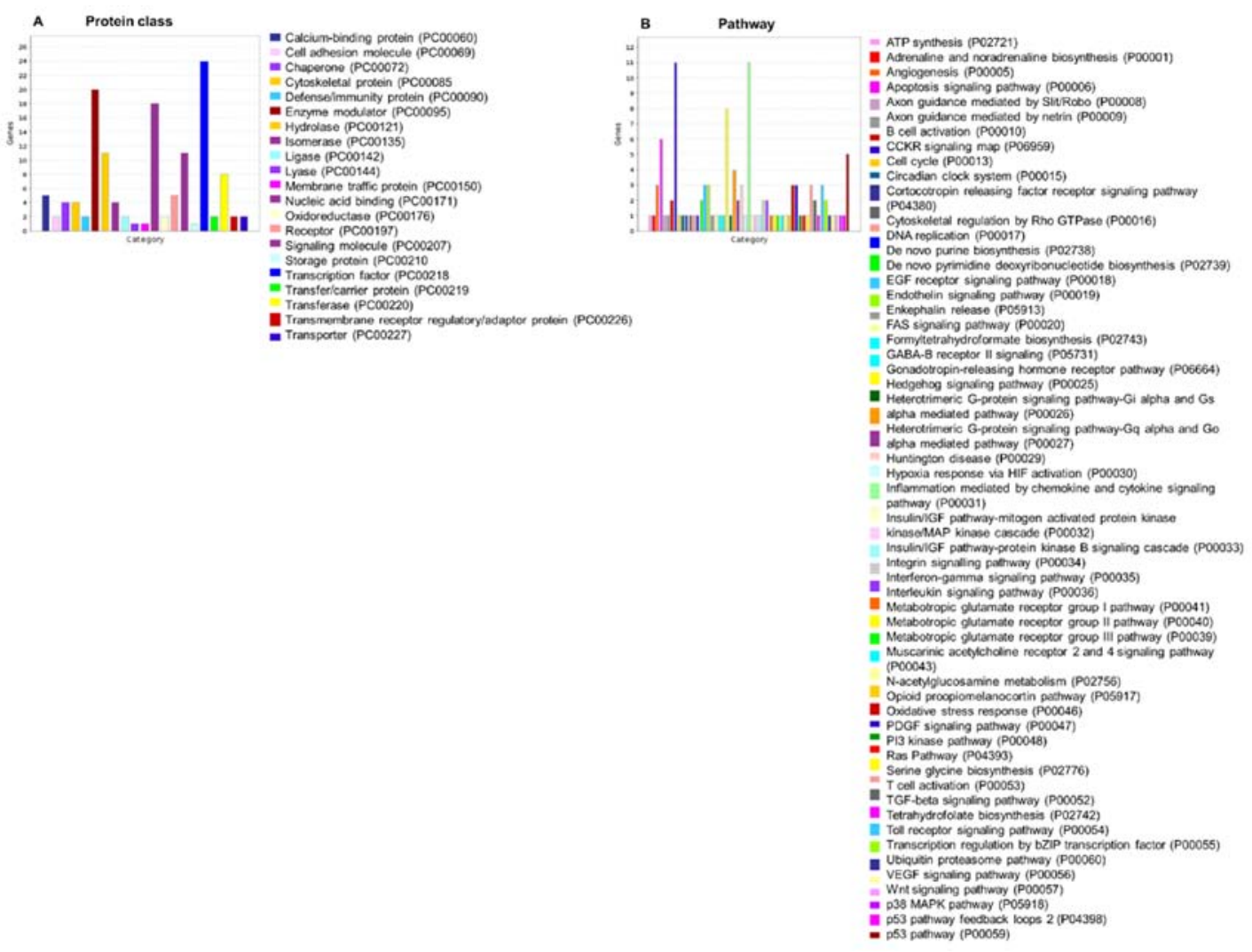

Figure 5. Analyzed protein class and pathways of DEGs in CHD. (A) The proteins of common DEGs were classified according to function. (B) Significantly enriched pathways of common DEGs.

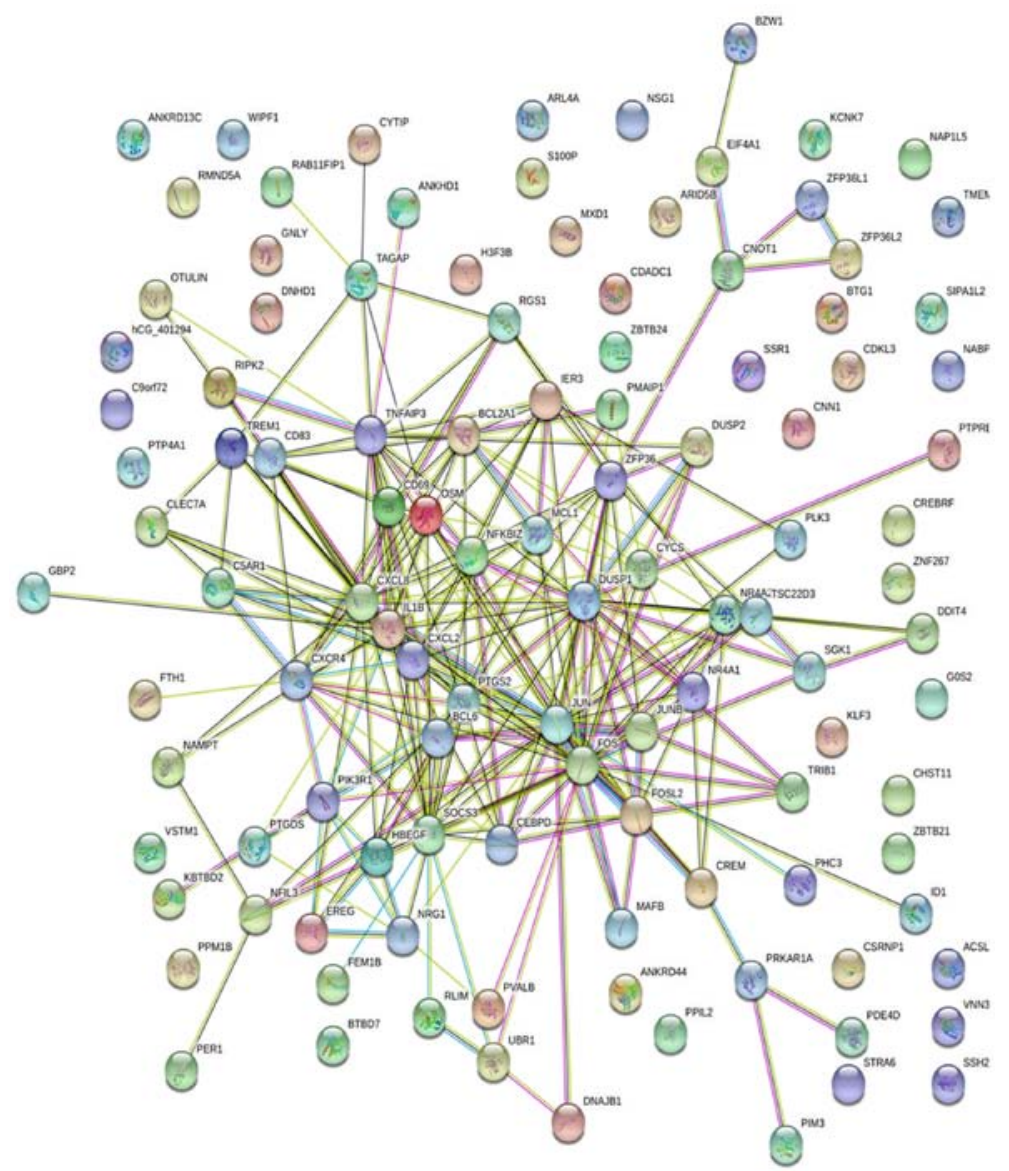

Figure 6. The CHD-associated data set PPI showing both gene interaction and binding properties. 
Table II. Pathway enrichment and reactome selected for CHD associated pathways.

\begin{tabular}{|c|c|c|c|c|c|c|c|}
\hline $\begin{array}{l}\text { Reactome } \\
\text { pathways }\end{array}$ & $\begin{array}{l}\text { Homo-sapiens } \\
\text { REFLIST } \\
\text { (20996) }\end{array}$ & $\begin{array}{c}\text { Client } \\
\text { text box } \\
\text { Input } \\
(212)\end{array}$ & $\begin{array}{l}\text { Client text } \\
\text { box input } \\
\text { (expected) }\end{array}$ & $\begin{array}{l}\text { Client text } \\
\text { box input } \\
\text { (over/under) }\end{array}$ & $\begin{array}{l}\text { Client text } \\
\text { box input } \\
\text { (fold } \\
\text { enrichment) }\end{array}$ & $\begin{array}{c}\text { Client } \\
\text { text box } \\
\text { input } \\
\text { (raw P-value) }\end{array}$ & $\begin{array}{l}\text { Client } \\
\text { text box } \\
\text { input } \\
\text { (FDR) }\end{array}$ \\
\hline $\begin{array}{l}\text { PI3K events in ERBB4 } \\
\text { signaling (R-HSA-1250342) }\end{array}$ & 9 & 4 & 0.09 & + & 44.02 & $6.47 \mathrm{E}-06$ & $3.54 \mathrm{E}-03$ \\
\hline $\begin{array}{l}\text { PI3K events in ERBB2 } \\
\text { signaling (R-HSA-1963642) }\end{array}$ & 13 & 4 & 0.13 & + & 30.47 & $2.09 \mathrm{E}-05$ & $6.53 \mathrm{E}-03$ \\
\hline $\begin{array}{l}\text { ERBB2 activates PTK6 } \\
\text { Signaling (R-HSA-8847993) }\end{array}$ & 11 & 3 & 0.11 & + & 27.01 & $3.30 \mathrm{E}-04$ & $4.53 \mathrm{E}-02$ \\
\hline $\begin{array}{l}\text { Chemokine receptors bind } \\
\text { chemokines (R-HSA-380108) }\end{array}$ & 48 & 6 & 0.48 & + & 12.38 & $1.61 \mathrm{E}-05$ & $5.88 \mathrm{E}-03$ \\
\hline $\begin{array}{l}\text { Interleukin-10 signaling } \\
\text { (R-HSA-6783783) }\end{array}$ & 45 & 5 & 0.45 & + & 11 & $1.40 \mathrm{E}-04$ & 2.79E-02 \\
\hline $\begin{array}{l}\text { Interleukin-4 and Interleukin-13 } \\
\text { signaling (R-HSA-6785807) }\end{array}$ & 111 & 12 & 1.12 & + & 10.71 & $3.96 \mathrm{E}-09$ & $8.68 \mathrm{E}-06$ \\
\hline $\begin{array}{l}\text { Peptide ligand-binding receptors } \\
\text { (R-HSA-375276) }\end{array}$ & 186 & 9 & 1.88 & + & 4.79 & $1.58 \mathrm{E}-04$ & $2.66 \mathrm{E}-02$ \\
\hline $\begin{array}{l}\mathrm{G} \text { alpha (i) signalling } \\
\text { events (R-HSA-418594) }\end{array}$ & 392 & 15 & 3.96 & + & 3.79 & $1.59 \mathrm{E}-05$ & $6.98 \mathrm{E}-03$ \\
\hline $\begin{array}{l}\text { Signaling by Interleukins } \\
\text { (R-HSA-449147) }\end{array}$ & 449 & 17 & 4.53 & + & 3.75 & 4.90E-06 & $3.58 \mathrm{E}-03$ \\
\hline $\begin{array}{l}\text { Class A/1 (Rhodopsin- } \\
\text { like receptors) (R-HSA-373076) }\end{array}$ & 321 & 12 & 3.24 & + & 3.7 & $1.40 \mathrm{E}-04$ & $2.56 \mathrm{E}-02$ \\
\hline $\begin{array}{l}\text { Cytokine signaling in } \\
\text { Immune system (R-HSA-1280215) }\end{array}$ & 669 & 23 & 6.76 & + & 3.4 & $4.96 \mathrm{E}-07$ & $5.43 \mathrm{E}-04$ \\
\hline $\begin{array}{l}\text { Generic transcription } \\
\text { Pathway (R-HSA-212436) }\end{array}$ & 1,094 & 26 & 11.05 & + & 2.35 & $6.61 \mathrm{E}-05$ & $1.45 \mathrm{E}-02$ \\
\hline $\begin{array}{l}\text { RNA polymerase II transcription } \\
\text { (R-HSA-73857) }\end{array}$ & 1,216 & 28 & 12.28 & + & 2.28 & $5.19 \mathrm{E}-05$ & $1.26 \mathrm{E}-02$ \\
\hline $\begin{array}{l}\text { Gene expression (transcription) } \\
\text { (R-HSA-74160) }\end{array}$ & 1,351 & 29 & 13.64 & + & 2.13 & $1.95 \mathrm{E}-04$ & $3.05 \mathrm{E}-02$ \\
\hline $\begin{array}{l}\text { Immune system } \\
\text { (R-HSA-168256) }\end{array}$ & 2,035 & 41 & 20.55 & + & 2 & 2.09E-05 & $5.73 \mathrm{E}-03$ \\
\hline $\begin{array}{l}\text { Signal transduction } \\
\text { (R-HSA-162582) }\end{array}$ & 2,667 & 46 & 26.93 & + & 1.71 & $2.66 \mathrm{E}-04$ & $3.89 \mathrm{E}-02$ \\
\hline
\end{tabular}

GO analysis, confirming the classes of proteins associated with CHD. Many genes associated with inflammatory roles, and a previous study showed a conserved signature of dilated cardiomyopathy (DCM) plays an important role in cell survival promotion during end-stage of heart failure (32). In the present study, we also revealed the expression pattern of apoptotic or inflammatory genes (Fig. 4) $(33,34)$.

Pathway analysis. To address the overview of data insight into the pathways, which are associated and connected for CHD development (35), we analyzed 164 DEGs involved in different functional pathways compared to reference and expected genes for those pathways. A total of 13 pathways were found to be associated with signaling-, immune-, and transcriptionrelated pathways (36). Genes were confirmed in the uploaded list over the expected one (number in the list divided by the expected number). If $>1$, it indicated that the category is overrepresented in the experiment. Conversely, the category is under-represented if $<1$. In the future, overexpressed genes are likely to serve as the marker selected in the development of CHD interventions. The P-value indicates the Fisher's exact test (37) or Binomial statistic in which the probability is the number of genes observed in this category occurred by chance (randomly), as determined by the reference list (Table II).

PPI analysis. To address the PPI of the CHD dataset in this study, STRING online suits was used to address the possible interaction of protein of CHD associated DEGs. A total of 112 nodes, 257 edges, 4.59 average node edge, 0.387 average clustering coefficient, 77 expected edge number, and $<1.0 \mathrm{e}-16$ PPI enrichment value were observed, and shown the network was significantly interacted than expected. Previous studies investigated the rare variants through targeted expression profiling across CHD relevant tissues from appropriate cases and controls $(38,39)$. The PPI indicates the interaction of genes associated with multiple genes for outcome. In the present study, we identified $422 \mathrm{GO}$ for biological process, $31 \mathrm{GO}$ for molecular function, $12 \mathrm{GO}$ for cellular component, 
Table III. Protein-protein interaction network of CHD associated genes.

A, Biological process (GO).

\begin{tabular}{|c|c|c|c|c|}
\hline S1. No & GO-term & Description & Count in gene set & False discovery rate \\
\hline 1 & GO:0050789 & Regulation of biological process & 100 of 11,116 & $2.85 \mathrm{e}-09$ \\
\hline 2 & GO:0065007 & Biological regulation & 101 of 11,740 & $2.13 \mathrm{e}-08$ \\
\hline 3 & GO:0050794 & Regulation of cellular process & 95 of 10,484 & $2.13 \mathrm{e}-08$ \\
\hline 4 & GO:0048523 & Negative regulation of cellular process & 59 of 4,454 & $2.13 \mathrm{e}-08$ \\
\hline 5 & GO:0048519 & Negative regulation of biological process & 62 of 4,953 & $2.13 \mathrm{e}-08$ \\
\hline
\end{tabular}

B, Molecular function (GO).

\begin{tabular}{lllcc}
\hline Sl. No & GO-term & Description & Count in gene set & False discovery rate \\
\hline 1 & GO:0000977 & $\begin{array}{l}\text { RNA polymerase II regulatory } \\
\text { region sequence-specific DNA binding }\end{array}$ & 16 of 647 & 0.00061 \\
2 & GO:0005515 & Protein binding & 62 of 6,605 & 0.00065 \\
3 & GO:0043565 & Sequence-specific DNA binding & 19 of 1,047 & 0.00083 \\
4 & GO:0140110 & Transcription regulator activity & 28 of 2,069 & 0.0011 \\
5 & GO:0005488 & binding & 89 of 11,878 & 0.0026 \\
\hline
\end{tabular}

C, Cellular components (GO).

\begin{tabular}{|c|c|c|c|c|}
\hline Sl. No & GO-term & Description & Count in gene set & False discovery rate \\
\hline 1 & GO:0005634 & Nucleus & 67 of 6,892 & $8.05 \mathrm{e}-05$ \\
\hline 2 & GO:0035976 & $\begin{array}{l}\text { Transcription factor AP-1 } \\
\text { complex }\end{array}$ & 3 of 5 & 0.0015 \\
\hline 3 & GO:0005622 & Intracellular & 102 of 14,286 & 0.0015 \\
\hline 4 & GO:0044424 & Intracellular part & 99 of 13,996 & 0.0064 \\
\hline 5 & GO:0043227 & $\begin{array}{l}\text { Membrane-bounded } \\
\text { organelle }\end{array}$ & 85 of 11,244 & 0.0067 \\
\hline
\end{tabular}

D, KEGG pathways.

\begin{tabular}{|c|c|c|c|c|}
\hline Sl. No & GO-term & Description & Count in gene set & False discovery rate \\
\hline 1 & hsa04668 & TNF signaling pathway & 9 of 108 & $4.47 \mathrm{e}-06$ \\
\hline 2 & hsa04380 & Osteoclast differentiation & 8 of 124 & $8.58 \mathrm{e}-05$ \\
\hline 3 & hsa04657 & IL-17 signaling pathway & 7 of 92 & $9.94 \mathrm{e}-05$ \\
\hline 4 & hsa04621 & $\begin{array}{l}\text { NOD-like receptor } \\
\text { signaling pathway }\end{array}$ & 8 of 166 & 0.00034 \\
\hline 5 & hsa05210 & Colorectal cancer & 6 of 85 & 0.00051 \\
\hline
\end{tabular}

E, Reactome pathways.

\begin{tabular}{|c|c|c|c|c|}
\hline Sl. No & GO-term & Description & Count in gene set & False discovery rate \\
\hline 1 & HSA-6785807 & $\begin{array}{l}\text { Interleukin-4 } \\
\text { and Interleukin-13 signaling }\end{array}$ & 11 of 106 & $3.07 \mathrm{e}-08$ \\
\hline 2 & HSA-449147 & Signaling by Interleukins & 14 of 439 & $6.23 \mathrm{e}-05$ \\
\hline 3 & HSA-1280215 & $\begin{array}{l}\text { Cytokine Signaling } \\
\text { in Immune system }\end{array}$ & 17 of 654 & $6.23 e-05$ \\
\hline 4 & HSA-1250342 & $\begin{array}{l}\text { PI3K events in } \\
\text { ERBB4 signaling }\end{array}$ & 4 of 9 & $7.21 \mathrm{e}-05$ \\
\hline 5 & HSA-1963642 & $\begin{array}{l}\text { PI3K events in } \\
\text { ERBB2 signaling }\end{array}$ & 4 of 13 & 0.00019 \\
\hline
\end{tabular}


Table III. Continued.

F, UniPort PFAM Protein domains

\begin{tabular}{|c|c|c|c|c|}
\hline Sl. No & Domain & Description & Count in gene set & False discovery rate \\
\hline 1 & PF07716 & Basic region leucine zipper & 7 of 44 & $2.23 \mathrm{e}-06$ \\
\hline 2 & PF03131 & bZIP Maf transcription factor & 5 of 33 & 0.00017 \\
\hline 3 & PF00170 & bZIP transcription factor & 5 of 36 & 0.00017 \\
\hline 4 & PF04553 & Tis11B like protein, $\mathrm{N}$ terminus & 2 of 2 & 0.0061 \\
\hline 5 & PF00782 & $\begin{array}{l}\text { Dual specificity phosphatase, } \\
\text { catalytic domain }\end{array}$ & 4 of 45 & 0.0061 \\
\hline
\end{tabular}

G, INTERPRO Protein Domains and Features

\begin{tabular}{lllcc}
\hline S1. No & Domain & \multicolumn{1}{c}{ Description } & Count in gene set & False discovery rate \\
\hline 1 & IPR004827 & Basic-leucine zipper domain & 8 of 54 & $7.06 \mathrm{e}-07$ \\
2 & IPR029021 & Protein-tyrosine phosphatase-like & 5 of 101 & 0.0181 \\
3 & IPR008917 & Transcription factor, Skn-1-like, & 3 of 16 & 0.0181 \\
4 & & DNA-binding domain superfamily & & 0.0181 \\
5 & IPR007635 & Tis11B-like protein, N-terminal & 2 of 2 & 0.0181 \\
\hline
\end{tabular}

SMART Protein Domains

\begin{tabular}{|c|c|c|c|c|}
\hline Sl. No & Domain & Description & Count in gene set & False discovery rate \\
\hline 1 & SM00338 & Basic region leucin zipper & 8 of 53 & $1.47 \mathrm{e}-07$ \\
\hline 2 & SM00195 & $\begin{array}{l}\text { Dual specificity phosphatase, } \\
\text { catalytic domain }\end{array}$ & 3 of 28 & 0.0246 \\
\hline 3 & SM00356 & Zinc finger & 3 of 42 & 0.0488 \\
\hline
\end{tabular}

33 pathways, 30 reactome pathways, 13 UniProt keywords, 11 PFAM protein domains, 29 INTERO protein domains, and 3 SMART protein domains in the analysis of CHD microarray data set. In those findings, associated edges shows physically binding protein and some of them were associated with but did not have physical binding. Of these, only the top-ranking ones have been presented (Fig. 6 and Table III).

Understanding and ruling the mechanism. There are several challenges to identifying the genetic basis of CHD that are also the determinants of this complex disease, including phenotypic and genetic heterogeneity, gene-environment, and etiological spectrum range and their effect. Considering research efforts involved in determining the genetic basis of this CHD, there is a need to understand the fine complexity of genetic association leading to mortality in developing countries. There is a need to focus on clinical manifestation rather than factors which influence or are heritable by genetic factors. There are many challenges in determining the genetic association of CHDs, such as phenotypic heterogeneity, genetic heterogeneity, small gene effects, gene-gene and gene-environment interactions and rare variants causing complex diseases. Some of the key points to be undertaken such as mortality, challenge in identifying the genetic determinants, studying linkage mapping through conventional approaches, and cataloguing of human diseases variation at single-nucleotide polymorphism (SNP), as well as genotyping will increase the likelihood of success.

In conclusion, we studied a comprehensive gene expression profile of microarray data of CHD. During the progression of CHD, there was a significant change in the expression of genes involved in the immune system, inflammation, and cell signaling through protein binding. This analysis provides valuable information for future research and in understanding the mechanism of CHD as well as identification of novel interventions for therapeutic application.

\section{Acknowledgements}

Not applicable

\section{Funding}

This research received no specific grants from any funding agencies.

\section{Availability of data and materials}

The datasets used and/or analyzed during the current study are available from the corresponding author on reasonable request. 


\section{Authors' contributions}

ZY conceived and designed the study. WL provided study materials. ZY, HM and WL were responsible for the collection and assembly of data, data analysis and interpretation. ZY was involved in writing the manuscript. All authors read and approved the final manuscript.

\section{Ethics approval and consent to participate}

Not applicable

\section{Patient consent for publication}

Not applicable

\section{Competing interests}

The authors declare that they have no competing interests.

\section{References}

1. Underlying Cause of Death 1999-2017. Centers for Disease Control and Prevention 24/7.

2. Haukilahti MAE, Holmström L, Vähätalo J, Kenttä T, Tikkanen J, Pakanen L, Kortelainen ML, Perkiömäki J, Huikuri H, Myerburg RJ, et al: Sudden cardiac death in women. Circulation 139: 1012-1021, 2019.

3. Ding D, Wang M, Su D, Hong C, Li X, Yang Y, Zhang Y, Hu G and Ling W: Body mass index, high-sensitivity C-reactive protein and mortality in Chinese with coronary artery disease. PLoS One 10: e0135713, 2015.

4. Yusuf S, Rangarajan S, Teo K, Islam S, Li W, Liu L, Bo J, Lou Q, $\mathrm{Lu}$ F, Liu T, et al: Cardiovascular risk and events in 17 low-, middle-, and high-income countries. N Engl J Med 371: 818-827, 2014.

5. Benjamin EJ, Blaha MJ, Chiuve SE, Cushman M, Das SR, Deo R, de Ferranti SD, Floyd J, Fornage M, Gillespie C, et al; American Heart Association Statistics Committee and Stroke Statistics Subcommittee: Heart disease and stroke statistics-2017 Update: A report from the American Heart Association. Circulation 135: e146-e603, 2017.

6. Mehta LS, Beckie TM, DeVon HA, Grines CL, Krumholz HM, Johnson MN, Lindley KJ, Vaccarino V, Wang TY, Watson KE, et al; American Heart Association Cardiovascular Disease in Women and Special Populations Committee of the Council on Clinical Cardiology, Council on Epidemiology and Prevention, Council on Cardiovascular and Stroke Nursing, and Council on Quality of Care and Outcomes Research: Acute myocardial infarction in women: A scientific statement from the American Heart Association. Circulation 133: 916-947, 2016.

7. Fyyaz S, Rauf A, Hudson J and Olabintan O: 107 Nice 2016 stable chest pain guidelines: Improved yield of severe coronary artery disease at invasive coronary angiography. Heart 105: 88, 2019.

8. Timmis A, Townsend N, Gale C, Grobbee R, Maniadakis N, Flather M, Wilkins E, Wright L, Vos R, Bax J, et al; ESC Scientific Document Group: European Society of Cardiology: Cardiovascular Disease Statistics 2017. Eur Heart J 39: 508-579, 2018.

9. Erbel R, Aboyans V, Boileau C, Bossone E, Bartolomeo RD, Eggebrecht H,Evangelista A, Falk V,Frank H, Gaemperli O, et al; ESC Committee for Practice Guidelines: 2014 ESC Guidelines on the diagnosis and treatment of aortic diseases: Document covering acute and chronic aortic diseases of the thoracic and abdominal aorta of the adult. Eur Heart J 35: 2873-2926, 2014.

10. Piepoli MF, Hoes AW, Agewall S, Albus C, Brotons C, Catapano AL, Cooney MT, Corrà U, Cosyns B, Deaton C, et al; ESC Scientific Document Group: 2016 European guidelines on cardiovascular disease prevention in clinical practice: The Sixth Joint Task Force of the European Society of Cardiology and Other Societies on Cardiovascular Disease Prevention in Clinical Practice (constituted by representatives of 10 societies and by invited experts) Developed with the special contribution of the European Association for Cardiovascular Prevention \& Rehabilitation (EACPR). Eur Heart J 37: 2315-2381, 2016.
11. Kwak BR, Bäck M, Bochaton-Piallat ML, Caligiuri G, Daemen MJAP, Davies PF, Hoefer IE, Holvoet P, Jo H and Krams R: Biomechanical factors in atherosclerosis: Mechanisms and clinical implications. Eur Heart J 35: 3013-3020 2014.

12. CARDIoGRAMplusC4D Consortium, Deloukas P, Kanoni S, Willenborg C, Farrall M, Assimes TL, Thompson JR, Ingelsson E, Saleheen D, Erdmann J: Large-scale association analysis identifies new risk loci for coronary artery disease. Nat Genet 45: 25-33, 2013.

13. Nikpay M, Goel A, Won H-H, Hall LM, Willenborg C, Kanoni S, Saleheen D, Kyriakou T, Nelson CP, Hopewell JC, et al: A comprehensive 1,000 genomes-based genome-wide association meta-analysis of coronary artery disease. Nat Genet 47: 11211130,2015

14. Kessler T, Vilne B and Schunkert H: The impact of genome-wide association studies on the pathophysiology and therapy of cardiovascular disease. EMBO Mol Med 8: 688-701, 2016.

15. Roberts R: Genetics of coronary artery disease. Circ Res 114: 1890-1903, 2014

16. Zhao Y, Chen J, Freudenberg JM, Meng Q, Rajpal DK and Yang X: Network-based identification and prioritization of key regulators of coronary artery disease loci. Arterioscler Thromb Vasc Biol 36: 928-941, 2016.

17. Miller CL, Pjanic M and Quertermous T: From locus association to mechanism of gene causality: The devil is in the details. Arterioscler Thromb Vasc Biol 35: 2079-2080, 2015.

18. Cheng Y and Zhang C: MicroRNA-21 in cardiovascular disease. J Cardiovase Transl Res 3: 251-255, 2010.

19. Chen CZ, Li L, Lodish HF and Bartel DP: MicroRNAs modulate hematopoietic lineage differentiation. Science 303: 83-86, 2003.

20. Johnson CD, Esquela-Kerscher A, Stefani G, Byrom M, Kelnar K, Ovcharenko D, Wilson M, Wang X, Shelton J, Shingara J, et al: The let-7 microRNA represses cell proliferation pathways in human cells. Cancer Res 67: 7713-7722, 2007.

21. Cheng AM, Byrom MW, Shelton J and Ford LP: Antisense inhibition of human miRNAs and indications for an involvement of miRNA in cell growth and apoptosis. Nucleic Acids Res 33: 1290-1297, 2005.

22. Smyth GK, Michaud J and Scott HS: Use of within-array replicate spots for assessing differential expression in microarray experiments. Bioinformatics 21: 2067-2075, 2005.

23. Mi H, Muruganujan A, Casagrande JT and Thomas PD: Large-scale gene function analysis with the PANTHER classification system. Nat Protoc 8: 1551-1566, 2013.

24. Jupe S, Fabregat A and Hermjakob H: Expression data analysis with reactome. Curr Protoc Bioinformatics 49: 8.20.1-8.20.9, 2015. https://doi.org/10.1002/0471250953.bi0820s49.

25. Szklarczyk D, Morris JH, Cook H, Kuhn M, Wyder S, Simonovic M, Santos A, Doncheva NT, Roth A, Bork P, et al: The STRING database in 2017: Quality-controlled protein-protein association networks, made broadly accessible. Nucleic Acids Res 45: D362-D368, 2017

26. Rana JS, Nieuwdorp M, Jukema JW and Kastelein JJ: Cardiovascular metabolic syndrome - an interplay of, obesity, inflammation, diabetes and coronary heart disease. Diabetes Obes Metab 9: 218-232, 2007.

27. Kessler T, Vilne B and Schunkert H: The impact of genome-wide association studies on the pathophysiology and therapy of cardiovascular disease. EMBO Mol Med 8: 688-701, 2016.

28. Torre-Amione G: Immune activation in chronic heart failure. Am J Cardiol 95 (11A): 3C-8C, discussion 38C-40C, 2005.

29. Brenes-Castro D, Castillo EC, Vázquez-Garza E, TorreAmione $G$ and García-Rivas G: Temporal frame of immune cell infiltration during heart failure establishment: Lessons from animal models. Int J Mol Sci 19: 19, 2018.

30. Flores-Arredondo JH, García-Rivas G and Torre-Amione G: Immune modulation in heart failure: Past challenges and future hopes. Curr Heart Fail Rep 8: 28-37, 2011.

31. Gu X, Li B, Jiang M, Fang M, Ji J, Wang A, Wang M, Jiang X and Gao C: RNA sequencing reveals differentially expressed genes as potential diagnostic and prognostic indicators of gallbladder carcinoma. Oncotarget 6: 20661-20671, 2015.

32. Barth AS, Kuner R, Buness A, Ruschhaupt M, Merk S, Zwermann L, Kääb S, Kreuzer E, Steinbeck G, Mansmann U, et al: Identification of a common gene expression signature in dilated cardiomyopathy across independent microarray studies. J Am Coll Cardiol 48: 1610-1617, 2006.

33. Satterthwaite G, Francis SE, Suvarna K, Blakemore S, Ward C, Wallace D, Braddock M and Crossman D: Differential gene expression in coronary arteries from patients presenting with ischemic heart disease: Further evidence for the inflammatory basis of atherosclerosis. Am Heart J 150: 488-499, 2005. 
34. Sinnaeve PR, Donahue MP, Grass P, Seo D, Vonderscher J, Chibout SD, Kraus WE, Sketch M Jr, Nelson C, Ginsburg GS, et al: Gene expression patterns in peripheral blood correlate with the extent of coronary artery disease. PLoS One 4: e7037, 2009.

35. Gotoh T, Endo M and Oike Y: Endoplasmic reticulum stressrelated inflammation and cardiovascular diseases. Int J Inflam 2011: 1-9, 2011.

36. Haas MJ and Mooradian AD: Regulation of high-density lipoprotein by inflammatory cytokines: Establishing links between immune dysfunction and cardiovascular disease. Diabetes Metab Res Rev 26: 90-99, 2010.

37. Costa THR, de Figueiredo Neto JA, de Oliveira AEF, Lopes e Maia MF and de Almeida AL: Association between chronic apical periodontitis and coronary artery disease. J Endod 40: 164-167, 2014
38. Jensen MK, Pers TH, Dworzynski P, Girman CJ, Brunak S and Rimm EB: Protein interaction-based genome-wide analysis of incident coronary heart disease. Circ Cardiovasc Genet 4: 549-556, 2011.

39. Duan S, Luo X and Dong C: Identification of susceptibility modules for coronary artery disease using a genome wide integraded network analysis. Gene: 531: 347-357, 2013

This work is licensed under a Creative Commons Attribution-NonCommercial-NoDerivatives 4.0 International (CC BY-NC-ND 4.0) License. 